Article

\title{
Susceptibility of Fall Armyworms (Spodoptera frugiperda J.E.) from Mexico and Puerto Rico to Bt Proteins
}

\author{
Rebeca Gutierrez-Moreno ${ }^{1}$, David Mota-Sanchez ${ }^{1, *}$, Carlos A. Blanco ${ }^{2}$, Desmi Chandrasena ${ }^{3}$, \\ Christina Difonzo ${ }^{1}$, Jeffrey Conner ${ }^{4}$, Graham Head ${ }^{5}$, Kristina Berman ${ }^{5}$ and John Wise ${ }^{1}$ \\ 1 Department of Entomology, Michigan State University, 1129 Farm Lane, East Lansing, MI 48824, USA; \\ gutie131@msu.edu (R.G.-M.); difonzo@msu.edu (C.D.); wisejohn@cns.msu.edu (J.W.) \\ 2 Department of Biology, University of New Mexico, Albuquerque, NM 87131, USA; \\ carlos.blanco1206@gmail.com \\ 3 Corteva Agriscience, Johnston, IA 50131, USA; desmi.chandrasena@corteva.com \\ 4 Department of Plant Biology, W. K. Kellogg Biological Station, Michigan State University, \\ Hickory Corners, MI 49060, USA; connerj@msu.edu \\ 5 Bayer U.S.-Crop Science, Chesterfield, MO 63017, USA; graham.head@bayer.com (G.H.); \\ kristina.berman@bayer.com (K.B.) \\ * Correspondence: motasanc@msu.edu; Tel.: +1-517-353-3435
}

Received: 2 November 2020; Accepted: 24 November 2020; Published: 26 November 2020

Simple Summary: Fall armyworms from Mexico are susceptible to four Bacillus thuringiensis (Bt) proteins, while those from Puerto Rico have field-evolved resistance to Cry1F and Cry1Ac and are susceptible to Cry2Ab2 and Cry1A.105. Implications for fall armyworm management are discussed.

\begin{abstract}
Fall armyworm is one of the main pests of conventional and Bacillus thuringiensis (Bt) corn in many countries in the Americas, Africa, Asia and in Australia. We conducted diet-overlay bioassays to determine the status of susceptibility to four Bt proteins (Cry1A.105, Cry2Ab2, Cry1F and Cry1Ac) in three different populations of fall armyworm from Mexico, and one population from Puerto Rico. Bioassays showed that fall armyworms from Puerto Rico were resistant to Cry1F with a resistance ratio ${ }_{50}\left(R R_{50}\right)$ higher than $10,000 \mathrm{ng} / \mathrm{cm}^{2}$ and to Cry1Ac with a $R R_{50}=12.2 \mathrm{ng} / \mathrm{cm}^{2}$, displaying the highest median lethal concentration $\left(\mathrm{LC}_{50}\right)$ values to all $\mathrm{Bt}$ proteins tested. The effective concentration ${ }_{50}\left(\mathrm{EC}_{50}\right)$ values further confirmed the loss of susceptibility to Cry1F and Cry1Ac in this population. However, $\mathrm{LC}_{50}$ and $\mathrm{EC}_{50}$ results with Cry1A.105 and Cry2Ab2 revealed that fall armyworm from Puerto Rico remained largely susceptible to these two proteins. The Mexican populations were highly susceptible to all the Bt proteins tested and displayed the lowest $\mathrm{LC}_{50}$ and $\mathrm{EC}_{50}$ values to all $\mathrm{Bt}$ proteins. Our results suggest that Cry1F and Cry1Ac resistance is stable in fall armyworm from Puerto Rico. However, this population remains susceptible to Cry1A.105 and Cry2Ab2. Results with Mexican fall armyworms suggest that possible deployment of Bt corn in Mexico will not be immediately challenged by Bt-resistant genes in those regions.
\end{abstract}

Keywords: Spodoptera frugiperda; resistance; $\mathrm{Bt}$ corn; bioassays; $\mathrm{LC}_{50} ; \mathrm{EC}_{50}$

\section{Introduction}

Fall armyworm Spodoptera frugiperda (J.E. Smith) (Lepidoptera: Noctuidae) is native to the Americas and is a major pest in the southern United States and Latin America, affecting important crops such as corn, rice, sorghum, and cotton [1,2]. On corn, larvae feed mainly on foliage, but occasionally feed in the ear [3,4]. Management of fall armyworm is complicated by its outstanding migratory 
capacity, as it can move long distances between countries and even regions [5]. In 2016, it was first detected in West Africa, and it spread to 28 African countries within a year of detection [6]. By 2020, fall armyworm was officially confirmed in Yemen, several countries in Southeast Asia, and Australia, threatening the production of not only corn, but rice, sorghum, and other crops $[7,8]$.

Fall armyworm management is also difficult because of its resistance to both foliar insecticides [9-12], and genetically engineered (GE) corn producing insecticidal proteins from Bacillus thuringiensis (Berliner) (Bt) [13-22]. In most Latin American countries, fall armyworm is considered the most important pest in both conventional and Bt corn production [23]. In many cases, additional synthetic insecticide sprays have been required to achieve satisfactory control levels in GE crops [23,24].

Fall armyworm populations have been described to display inherent low susceptibility to the Bt proteins Cry1 Ab and Cry1Ac $[19,25,26]$. Yet, the first report of unexpectedly high damage in Bt corn by fall armyworm occurred in Puerto Rico, 10 years after the introduction of Bt maize (TC1507) producing Cry1F $[13,14]$. Since then, field-evolved resistance cases have been reported in Puerto Rico to Cry1F, Cry1Ac and Cry1Ab [13-15]; in Brazil to Cry1F and Cry1Ab [16-18]; in the southeastern United States to Cry1A.105 and Cry1F [19,21]; and in Argentina to Cry1F [22].

Fall armyworm is the main corn pest in Puerto Rico. Since pyramided Bt maize production on this island is mainly grown for hybrid seed increase and research, acceptance of pest damage is very low, which has led to a high number of insecticide applications to control fall armyworm [10,12,23]. This means that fall armyworm is under strong selection pressure, which has caused resistance to evolve to different insecticide modes of action [12], in addition to the reported resistance to Cry1F and Cry1Ac $[13,14,27]$. Factors such as weather conditions, relative isolation and continuous generation of fall armyworm contributed to the first reported evolution of resistance to Bt proteins in Puerto Rico [15]. Although weather conditions are variable, relative isolation and continuous generation are a constant on this island. Furthermore, pyramided corn hybrids grown in Puerto Rico still contain Cry1F, with the addition of Cry1A.105 and Cry2Ab2. Since there have been reports of cross-resistance between Cry1 proteins in South America [28], it is important to monitor the susceptibility status of fall armyworms from Mexico and Puerto Rico to Bt corn because of the potential migration of resistant fall armyworms to Mexico.

In Mexico, fall armyworm is the hardest pest to manage in most corn producing regions, and control relies heavily on synthetic insecticide sprays and Bt corn technology is not commercially available $[12,23,29]$. Farmers spray insecticides two or three times per crop cycle to control fall armyworm and other insect pests, using mostly organophosphates and pyrethroids [23,29]. However, some growers report that they spray up to 12 times to control fall armyworm (Mota-Sanchez D, unpublished). The use of synthetic insecticides as the sole control measure can lead to problems such as the evolution of resistance to the commonly used chemistries, loss of arthropod biodiversity by affecting non-target organisms, and environmental pollution. However, the heterogeneity of corn production in Mexico, which ranges from small subsistence farms to large commercial enterprises, complicates the application of effective integrated pest management (IPM) strategies throughout the country [29].

Monitoring the susceptibility of target pests to control tools is a key component in IPM programs, as it allows for changes in management tactics before resistance is fixed in a population [30]. Knowing the level of susceptibility of a pest to a pesticide before the technology is deployed in the field can help strategically plan its application. Fall armyworm populations from different regions in Latin America have displayed variability in their susceptibility to Bt proteins [31]. Therefore, the objective of this study was to determine and compare the susceptibility status of different populations of fall armyworm to Cry1F, Cry1Ac, Cry1A.105 and Cry2Ab2. These populations were from three different locations in Mexico, where the larvae have not been exposed to Bt corn, and from one location in Puerto Rico, where the larvae have been in contact with Bt expressing corn for over a decade. 


\section{Materials and Methods}

\subsection{Field and Laboratory Fall Armyworm Populations}

Fall armyworm larvae from Mexico were collected during summer 2015 in cornfields from the Northwest (Los Mochis, Sinaloa (Sin)), West Central (San Martin de Hidalgo, Jalisco (Jal)) and Southwest (San Pablo Huitzo and San Lorenzo Cacaotepec Etla, Oaxaca (Oax)). San Pablo Huitzo and San Lorenzo Cacaotepec are located about $30 \mathrm{~km}$ apart from each other. The corn fields where fall armyworms were collected in Oaxaca share weather conditions and agronomical practices, since they belong to small subsistence farmers. Therefore, fall armyworms were pooled together and their progeny (F1-F3) were used in the bioassays.

Larvae from Puerto Rico (PR) were collected in June to November 2016. Bayer Crop Science (formerly Monsanto, St. Louis, MO, USA) provided a fall armyworm susceptible laboratory (Sus) population from their rearing facilities in Union City, Tennessee.

For each population, a minimum of 200 fourth- and fifth-instar larvae were collected directly from maize plants. Larvae were placed in $10 \mathrm{~mL}$ plastic cups with 4-6 mL of artificial diet (Southland Products Incorporated: fall armyworm diet), and sent to our laboratory at Michigan State University, East Lansing, Michigan, United States.

\subsection{Insect Rearing}

Larvae were held at $27 \pm 1^{\circ} \mathrm{C}$ and a photoperiod of 16:8(L:D) h. Insect development was recorded every other day. When pupae changed colors from orange-red to dark red, they were placed in collapsible insect cages (Bioquip, Rancho Dominguez, CA, USA) in groups of 40 individuals, to provide room for emerging adults to fly and mate. A sponge with a solution of $10 \%$ sucrose was placed inside the cages and replenished every other day. After three days of adult emergence, adults from each cage were placed in $1 \mathrm{~L}$ paper brown bags with the same food source. Moths were transferred to a new paper bag every other day. The eggs masses laid in the paper bag were separated and placed in a plastic container with moist paper towels. Neonate larvae were transferred to bioassay trays (Frontier Agricultural Sciences, Newark, DE, USA) with $1 \mathrm{~mL}$ of artificial diet per well.

\subsection{Bt Proteins}

Corteva Agriscience (formerly Dow AgroSciences LLC, Indianapolis, IN, USA) provided lyophilized Cry1F and Cry1Ac proteins and $10 \mathrm{mM}$ 3-(cyclohexylamino)-1-propane sulfonic acid (CAPS buffer), diluted in deionized water, $\mathrm{pH}$ 10.5. Proteins were kept in a desiccator (Fisher Scientific rectangular Desi-Vac Container ${ }^{\mathrm{TM}}$ ), both proteins and buffer stored in a refrigerator at $4{ }^{\circ} \mathrm{C}$.

Bayer Crop Science (formerly Monsanto, St. Louis, MO, USA) provided Cry1A.105 (80\% purity, concentration $1 \mathrm{mg} / \mathrm{mL})$ and Cry2Ab2 (87\% purity, concentration $0.31 \mathrm{mg} / \mathrm{mL})$ in $1 \mathrm{~mL}$ aliquots. Cry1A.105 arrived diluted in 25 mM CAPS buffer, pH 10.3 and $1 \mathrm{mM}$ benzamidine- $\mathrm{HCl}$, 0.1 ethylenediaminetetraacetic acid (EDTA) and $0.2 \mathrm{mM}$ dehydrochlorinase (DDT). Cry2Ab2 arrived diluted in 50 mM CAPS buffer, pH 11 and 2 mM DTT. Additionally, Bayer Crop Science also provided both buffers to make the dilutions used in the bioassays. Proteins and buffers were held in a $-80{ }^{\circ} \mathrm{C}$ freezer.

\subsection{Bioassays}

Bioassays were conducted over the following timeframes: Mexican populations, July 2015 to November 2016; Sus population, June 2014 to February 2017; PR population, June 2016 to February 2017.

Diet overlay bioassays were conducted using the procedure described by Storer et al. [14] using 128-well bioassay trays (Frontier ${ }^{\mathrm{TM}}$ Agricultural Sciences), with $1 \mathrm{~mL}$ of fall armyworm artificial diet dispensed per well with a surface area of $1.5 \mathrm{~cm}^{2}$. Table 1 shows the concentration range used for each population and each protein. A total of $100 \mu \mathrm{L}$ of each concentration was applied over the diet surface on each well. Two controls were used, which consisted of: (1) diet alone and (2) diet plus the 
appropriate CAPS buffer. After treatments dried in the wells, one neonate was placed in each well with a small paintbrush. Only healthy, actively moving neonates were chosen for the experiments. Mortality and weight were evaluated seven days after treatment. Larvae that failed to move after prodding, failed to molt to second instar, or weighing $\leq 0.1 \mathrm{mg}$ were considered dead $[16,17,27]$.

Table 1. Bacillus thuringiensis (Bt) protein concentrations used in concentration-mortality response bioassays.

\begin{tabular}{ccc}
\hline Population & Bt Protein & Concentration Range $\left.\mathbf{( n g} / \mathbf{c m}^{2}\right)$ \\
\hline \multirow{3}{*}{ Susceptible } & Cry2Ab2 & $10-1000$ \\
& Cry1A.105 & $10-1000$ \\
& Cry1F & $7.4-1000$ \\
& Cry1Ac & $7.4-1300$ \\
\hline \multirow{3}{*}{ Jalisco } & Cry2Ab2 & $0.7-200$ \\
Oaxaca & Cry1A.105 & $0.02-67$ \\
& Cry1F & $7.4-1000$ \\
& Cry1Ac & $7.4-1000$ \\
Sinaloa & Cry2Ab2 & $22.2-1300$ \\
& Cry1A.105 & $22.2-1300$ \\
& Cry1F & $7.4-1000$ \\
& Cry1Ac & $22.2-1300$ \\
\hline \multirow{3}{*}{ Puerto Rico } & Cry2Ab2 & $7.4-6000$ \\
& Cry1A.105 & $7.4-6000$ \\
& Cry1F & $22.2-10,000$ \\
& Cry1Ac & $22.2-6000$ \\
\hline
\end{tabular}

Robertson et al. [32] indicated that 120 individuals in a sample size is sufficient to conduct an insecticide bioassay. For each Bt protein, our work includes between 253-770 individuals. A single repetition consisted of 16 neonates per concentration. Three to five repetitions were conducted per $\mathrm{Bt}$ protein with six concentrations covering $0-100 \%$ mortality, as determined by previous experiments with diagnostic concentrations. For the PR population, 100\% mortality was not achieved with the Cry1F and Cry1Ac proteins.

\subsection{Statistical Analysis}

Mortality data were corrected using Abbott's formula [33]. Probit analysis [34] was conducted using SAS version 9.3 [35] to calculate values of the slope, the concentration that killed $50 \%$ of the larvae $\left(\mathrm{LC}_{50}\right)$, the lethal concentration conferring ninety percent mortality ( $\mathrm{LC}_{90}$ ), and fiducial limits (95\%) for each population. Resistance ratios were calculated by dividing the $\mathrm{LC}_{50}$ values of each field population by the $\mathrm{LC}_{50}$ value of the susceptible colony. Log-concentration responses were plotted using Origin ${ }^{\circledR}[36]$.

The effective concentration of each Bt protein that is expected to reduce larval weight by $50 \%$ $\left(\mathrm{EC}_{50}\right)$ and confidence intervals $(\mathrm{CI})$ were estimated using a non-linear regression analysis in SAS version 9.335, using the logistic model described by Sims et al. [37]:

$$
\text { Weight }=\mathrm{W} 0 /\left[1+\left(\text { dose } / \mathrm{EC}_{50}\right) \mathrm{b}\right]
$$

\section{Results}

There was a clear difference in Bt protein susceptibility between the Mexican and Puerto Rican field populations (Tables 2 and 3). The greatest differences were observed in the $L_{50} \mathrm{~S}_{\text {and }} \mathrm{EC}_{50} \mathrm{~s}$ for Cry1F and Cry1Ac, with larvae from the Mexican populations needing the lowest concentrations, while larvae from the PR population requiring approximately 12- to 100-fold more (Figure 1, Tables 2 and 3). Thus, for PR, the $\mathrm{LC}_{50}$ and $\mathrm{EC}_{50}$ values for Cry1F were close to or greater than $10,000 \mathrm{ng} / \mathrm{cm}^{2}$, which was the highest concentration that could be attained with the stock solution. 
Table 2. Concentration-mortality response $\left(\mathrm{ng} / \mathrm{cm}^{2}\right)$ of fall armyworm from several Mexican states and Puerto Rico to Bt proteins.

\begin{tabular}{|c|c|c|c|c|c|c|c|c|c|c|}
\hline Bt Protein & Pop ${ }^{a}$ & $n^{b}$ & $\mathrm{LC}_{50}{ }^{\mathrm{c}}$ & $95 \% \mathrm{FL}^{\mathrm{d}}$ & $\mathrm{RR}_{50} \mathrm{e}$ & $\mathrm{LC}_{90}{ }^{\mathrm{c}}$ & $95 \% \mathrm{FL}^{\mathrm{d}}$ & $\mathrm{RR}_{90} \mathrm{e}^{\mathrm{s}}$ & $\begin{array}{l}\text { Slope } \\
\pm \text { SE }^{f}\end{array}$ & $X^{2} g$ \\
\hline \multirow{5}{*}{ Cry1F } & SUS & 338 & 174.4 & $135.7,222.6$ & 1.0 & 849 & $606.6,1349$ & 1.0 & $1.9 \pm 0.2$ & 0.9 \\
\hline & SIN & 624 & 29.2 & $22.6,36.7$ & 0.2 & 201 & 145,309 & 0.2 & $1.5 \pm 0.1$ & 2.8 \\
\hline & JAL & 384 & 42.8 & $29.8,59.8$ & 0.2 & 463 & $275.4,1015$ & 0.5 & $1.2 \pm 0.2$ & 4.3 \\
\hline & OAX & 384 & 26.5 & $0.03,122$ & 0.2 & 502 & $113,1.92 \times 10^{12}$ & 0.6 & $1 \pm 0.3$ & 2.5 \\
\hline & PR & 256 & $>10,000$ & $\mathrm{Ne}^{h}$ & ne & $>10,000$ & ne & ne & ne & ne \\
\hline \multirow{5}{*}{ Cry1Ac } & SUS & 770 & 148.2 & $120,183.2$ & 1.0 & 1050 & $750.3,1635$ & 1.0 & $1.5 \pm 0.1$ & 4.0 \\
\hline & SIN & 512 & 15.3 & 8,22 & 0.1 & 78 & 57,125 & 0.1 & $1.8 \pm 0.3$ & 0.3 \\
\hline & JAL & 380 & 34.2 & $20.5,52.3$ & 0.2 & 817.7 & $397.9,2781$ & 0.8 & $0.9 \pm 0.1$ & 1.5 \\
\hline & OAX & 385 & 188.8 & 132,280 & 1.3 & 3262 & 1669,8983 & 3.1 & $1 \pm 0.1$ & 3.4 \\
\hline & PR & 624 & 1815 & $934.5,5374$ & 12.2 & 705,419 & $95,917,>100,000$ & 671.8 & $0.5 \pm 0.08$ & 1.4 \\
\hline \multirow{5}{*}{ Cry1A.105 } & SUS & 641 & 201.9 & $150.4,266.3$ & 1 & 859 & $586.6,1576$ & 1 & $2 \pm 0.3$ & 4.5 \\
\hline & SIN & 383 & ne & ne & ne & ne & ne & ne & ne & ne \\
\hline & JAL & 256 & 4.6 & $3.2,6.4$ & 0.02 & 28.3 & $17.8,57.5$ & 0.03 & $1.6 \pm 0.2$ & 4.5 \\
\hline & OAX & 560 & 14.5 & $3.4,139.7$ & 0.07 & 164.4 & $37.8,>100,000$ & 0.2 & $1.2 \pm 0.3$ & 5.8 \\
\hline & PR & 303 & 273.8 & $172.5,442.8$ & 1.4 & 3234 & $1542,12,547$ & 3.8 & $1.2 \pm 0.2$ & 1.4 \\
\hline \multirow{5}{*}{ Cry2Ab2 } & SUS & 640 & 173.2 & $130.8,214.1$ & 1 & 469 & $373.5,649.9$ & 1 & $3 \pm 0.4$ & 5 \\
\hline & SIN & 381 & ne & ne & ne & ne & ne & ne & ne & ne \\
\hline & JAL & 256 & 49.7 & $30.3,94$ & 0.2 & 1040 & $398.9,5369$ & 2.7 & $0.9 \pm 0.1$ & 3.2 \\
\hline & OAX & 410 & 13.3 & $3.1,165.5$ & 0.1 & 1762 & $150.3,>100,000$ & 4.6 & $0.6 \pm 0.2$ & 2.4 \\
\hline & PR & 253 & 119.2 & $68.5,187$ & 0.5 & 2092 & 1091,6065 & 5.5 & $1 \pm 0.2$ & 0.4 \\
\hline
\end{tabular}

a Fall armyworm population, ${ }^{\mathrm{b}}$ total number of insects used, ${ }^{\mathrm{c}}$ lethal concentration (LC) expressed in nanograms of active ingredient per square centimeter of diet (ng/ $\mathrm{cm}^{2}$ ), ${ }^{\mathrm{d}}$ fiducial limits, ${ }^{\mathrm{e}}$ resistance ratio $=\mathrm{LC}$ of fall armyworm field population over the LC of the susceptible reference population, ${ }^{\mathrm{f}}$ probit slope \pm standard error $(\mathrm{SE}),{ }^{\mathrm{g}} \mathrm{chi}-\mathrm{square}$ value, ${ }^{\mathrm{h}}$ ne $=\mathrm{not}^{\mathrm{n}}$ estimated due to insufficient response to treatments. 
Table 3. Effective concentration of Bt proteins that is expected to reduce weight by $50 \%\left(\mathrm{ng} / \mathrm{cm}^{2}\right)$ in fall armyworm from several Mexican states and Puerto Rico.

\begin{tabular}{cccccc}
\hline Bt Protein & Pop $^{\mathbf{a}}$ & $\mathbf{n}^{\mathbf{b}}$ & EC50 $^{\mathbf{c}}$ & $\mathbf{S E}^{\mathbf{d}}$ & $\mathbf{9 5 \%} \mathbf{C I}^{\mathbf{e}}$ \\
\hline \multirow{5}{*}{ Cry1F } & SUS & 338 & 11 & 1.3 & $8.2,13.4$ \\
& SIN & 624 & 16 & 1.4 & $12.5,18.7$ \\
& JAL & 384 & 5 & 1.2 & $2.3,7.4$ \\
& OAX & 384 & 7 & 0.8 & $5.2,8.8$ \\
& PR & 256 & $>10,000$ & ne & ne \\
\hline \multirow{5}{*}{ Cry1Ac } & SUS & 770 & 5 & 1.1 & $2.4,6.9$ \\
& SIN & 512 & 23 & 0.2 & $22.1,23.5$ \\
& JAL & 380 & 1.6 & 0.6 & $0.4,2.8$ \\
& OAX & 385 & 3 & 0.6 & $1.5,4$ \\
& PR & 624 & 68 & 10.8 & 43,92 \\
\hline \multirow{5}{*}{ Cry1A.105 } & SUS & 641 & 31 & 5 & $19.6,42.8$ \\
& SIN & 383 & ne & ne & ne \\
& JAL & 256 & 1.3 & 0.2 & $0.9,1.8$ \\
& OAX & 560 & 1.4 & 0.3 & $0.8,2.2$ \\
& PR & 303 & 73.1 & 9.3 & $51.7,94.4$ \\
\hline \multirow{5}{*}{ Cry2Ab2 } & SUS & 640 & 111 & 27 & $52.4,169.6$ \\
& SIN & 381 & ne & ne & ne \\
& JAL & 256 & 5.4 & 1.4 & $2.3,8.5$ \\
& OAX & 410 & 1.1 & 0.2 & $0.7,1.6$ \\
& PR & 253 & 24.7 & 5.8 & $11.7,37.7$
\end{tabular}

a Fall armyworm population, ${ }^{b}$ total number of insects used, ${ }^{c}$ effective concentration of Bt protein that is expected to reduce larval weight by $50 \%$ expressed in nanograms of active ingredient per square centimeter of diet $\left(\mathrm{ng} / \mathrm{cm}^{2}\right)$, ${ }^{d}$ standard error, ${ }^{e}$ confidence intervals, ne $=$ not estimated due to insufficient response to treatments.

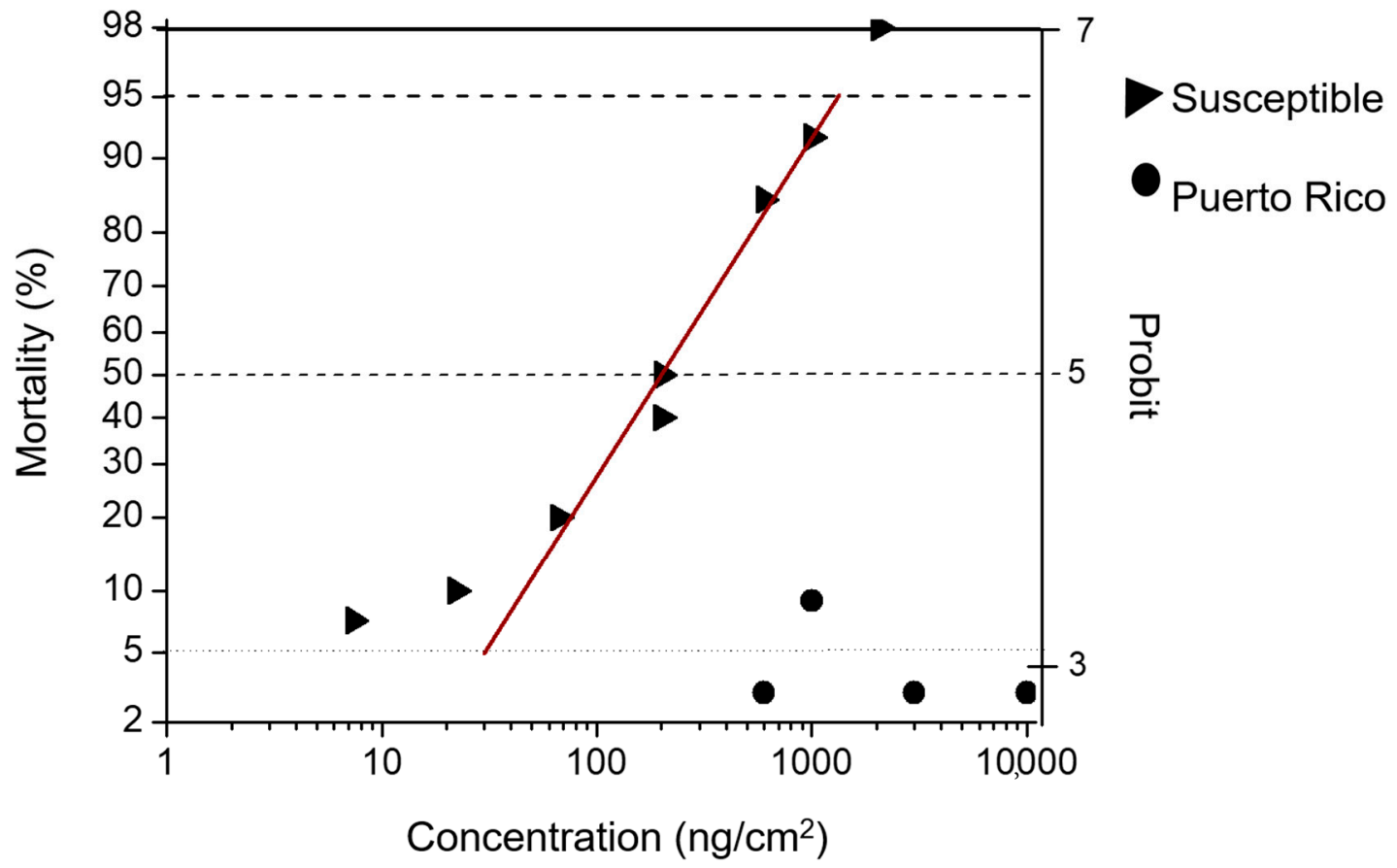

Figure 1. Log concentration-mortality in diet-overlay bioassays to Cry1F. The fall armyworm susceptible laboratory colony (triangles) versus a fall armyworm field population collected in Puerto Rico (circles).

Even with the highest dose of Cry1Ac, only $62 \%$ mortality was achieved in the PR population, so the $\mathrm{LC}_{50}$ and $\mathrm{EC}_{50}$ values have wide fiducial limits and confidence intervals, respectively. Moreover, the slope value obtained with Cry1Ac in the PR population was significantly lower than the values 
obtained with the Mexican field populations and the susceptible reference. This indicates that higher protein concentrations are needed in PR fall armyworms to reach a similar mortality response than in the other populations tested. Indeed, this can be observed at the $\mathrm{LC}_{90}$ level, where the concentration that is predicted to kill $90 \%$ of the population increased 671.8 -fold from the concentration estimated for the susceptible reference population.

Reduced weight gain as a sublethal effect of the Bt protein's activity in the insect's midgut was measured using the $\mathrm{EC}_{50}$ parameter. Therefore, this parameter provides a more sensitive insight into the changes in susceptibility that go beyond the acute toxicity measured by the $\mathrm{LC}_{50}$. This is evident in the PR population, where $100 \%$ mortality was not achieved with the highest concentration of Cry1Ac, but the reduced weight gain was enough to calculate an $\mathrm{EC}_{50}$ value that was 26.7 -fold lower than the $\mathrm{LC}_{50}$ value. This shows that Cry1Ac still has biological activity against this fall armyworm population from Puerto Rico, yet it is arguable whether this is enough to achieve effective field control. In contrast, fall armyworms from Mexico showed low $\mathrm{LC}_{50}$ values with Cry1Ac; in particular, the Sin and Jal populations were statistically more susceptible to this protein than the susceptible reference population, as seen by their non-overlapping fiducial limits.

The Mexican and PR (to a lesser extent) fall armyworm populations were susceptible to Cry1A.105 in comparison with the reference susceptible population at both $\mathrm{LC}_{50}$ and $\mathrm{EC}_{50}$ levels. Both Jal and Oax were significantly more susceptible to Cry1A.105 than both the susceptible reference and PR populations, since their $\mathrm{LC}_{50}$ fiducial limits and $\mathrm{EC}_{50}$ confidence intervals do not overlap. PR fall armyworms showed a similar level of susceptibility to the susceptible reference population to Cry1A.105 based on the $\mathrm{LC}_{50}$ as observed by their overlapping fiducial limits. However, for the $\mathrm{EC}_{50}$, the PR fall armyworms were 2.4-fold less susceptible than the susceptible reference.

For Cry2Ab2, though all populations are susceptible to this protein, the slope value for the susceptible reference is significantly steeper than the one obtained for the field populations. This could indicate that the field fall armyworms tested have a higher degree of variability in their response to this specific protein than the susceptible reference. For the $\mathrm{LC}_{50}$, Jal is the only field population we tested with non-overlapping fiducial limits with the susceptible reference. Still, if we look at the $\mathrm{EC}_{50}$, both Jal and Oax show lower values with non-overlapping confidence intervals relative to both the susceptible and PR populations, which could mean that these populations are more sensitive to Cry2Ab2.

For the Sin population, 100\% mortality was achieved at the lowest concentrations of Cry1A.105 and Cry2Ab2 used $\left(22.2 \mathrm{ng} / \mathrm{cm}^{2}\right)$. Therefore, neither $\mathrm{LC}_{50}$ nor $\mathrm{EC}_{50}$ values were calculated.

Overall, both $\mathrm{LC}_{50}$ and $\mathrm{EC}_{50}$ values indicate that the fall armyworm populations from Mexico are highly susceptible to all of the Bt proteins tested, while only Cry2Ab2 and Cry1A.105 remain effective against the PR population.

\section{Discussion}

Fall armyworms from Puerto Rico showed resistance to Cry1F and Cry1Ac, while remaining susceptible to Cry1A.105 and Cry2Ab2, despite being exposed to these proteins for several years. Additionally, our study shows that fall armyworm from Mexico displayed low $\mathrm{LC}_{50}$ and $\mathrm{EC}_{50}$ values to the four purified proteins Cry1F, Cry1Ac, Cry2Ab2, and Cry1A.105. To the best of our knowledge, this is the first official report of the status of fall armyworm susceptibility to Cry1A.105 and Cry2Ab in Mexican field-collected populations.

Previous analysis with Cry1Fa and Cry1Ac with populations collected from the states of Tamaulipas and Estado de Mexico has also shown high susceptibility of fall armyworm to this technology [13]. Furthermore, a recent publication with populations from the Mexican states (Baja California Sur, Chihuahua, Coahuila, Durango, Sinaloa, Sonora, and Tamaulipas) has also reported that fall armyworm is susceptible to Cry1F [38]. Their LC $_{50}$ results in several populations from Sinaloa ranged from 29.4 to $107.2 \mathrm{ng} / \mathrm{cm}^{2}$ [38], this is consistent with the results we obtained with our Sin population, displaying an $\mathrm{LC}_{50}$ of $29.2(22.6-36.7) \mathrm{ng} / \mathrm{cm}^{2}$. 
The first reports of fall armyworm resistance to Cry1F occurred in Puerto Rico [13,14], in populations collected in 2007 and 2008. Our data indicate that fall armyworm from PR are still highly resistant to Cry1F, 10 years after Cry1F expressing Bt maize (TC1507) was removed from the field. Our finding extends the bioassay results by Vélez et al. [39], which show high levels of fall armyworm resistance to Cry1F in PR between 2010 and 2013. Strong selection to Cry1F has been discontinued in Puerto Rico due to the reduced deployment of hybrids containing Cry1F; however, some of the new pyramided Bt corn hybrids that are grown on the island contain Cry1F in combination with other Bt proteins.

Resistance to Cry1F in fall armyworms from Puerto Rico has been described as recessive, conferred by a single, autosomal locus, and with no maternal effects [14,39]. The molecular mechanism of Cry1F resistance in fall armyworm from Puerto Rico and Brazil was characterized as a reduction or complete lack of Cry1F binding to the brush border membrane vesicles (BBMV) in the midgut [31,40]. The authors have proposed that this resistance mechanism is responsible for high levels of cross-resistance to Cry1Aa proteins in populations with field-evolved Cry1F resistance. However, a 2017 study [41] has reported that the field-evolved resistance to Cry1Fa in fall armyworms from Puerto Rico is closely linked to a mutation in an ATP-binding cassette subfamily C2 (ABCC2) gene. This protein has a role as a Cry1Fa receptor in susceptible insects. Low or no cross-resistance has been found to other Cry proteins, such as Cry1Ac, Cry1Ab, and Cry2A [14,31,39,42].

Cry1Ac has been described as having low biological activity against fall armyworm, to the point that it is deemed ineffective [43,44]. Our results show that a Cry1F-resistant fall armyworm from Puerto Rico also displayed a high resistance ratio to Cry1Ac when compared with the susceptible reference. Furthermore, it was demonstrated that Cry1A and Cry1F share midgut-specific binding sites, in both fall armyworm and the European corn borer (Ostrinia nubilalis), meaning that cross-resistance between these two proteins might be possible [45]. Although Storer et al. [14] suggested that Cry1Ac and Cry1F do not share the same binding site in the insect's midgut, the data presented here suggest the opposite. Specifically, our study shows that fall armyworms from the Puerto Rican population are highly resistant to Cry1Ac, despite their lack of prior exposure. On the other hand, fall armyworms from the Mexican populations tested were highly susceptible. The major difference between these populations is prior exposure to Cry1F. Consistent with cross-resistance between Cry1F and Cry1Ac, only fall armyworms from Puerto Rico have a history of Cry1F exposure. Consistent with this observation, an alternative resistance mechanism has been described in fall armyworms from Puerto Rico, a mutation in the receptor SfABCC2 that binds both Cry1Fa/Cry1A [41]. Since this mutation was detected in fall armyworm individuals from Puerto Rico since 2009, resistance to Cry1Ac could be explained as a case of cross-resistance to Cry1F. Screening for the presence of this SfABCC2 mutation in fall armyworms from Ponce, Puerto Rico could help confirm this hypothesis.

Some pyramided Bt corn hybrids containing Cry1A.105 and Cry2Ab2 in addition to Cry1F have been grown in Puerto Rico since the detection of field-evolved resistance to Cry1F [15]. This means that fall armyworm in Puerto Rico has been exposed to these two proteins for at least four years before the present study. Cry1A.105 is a chimeric Bt protein comprised by domain exchange from Cry1Ab (domain I), Cry1Ac1 (domain II), Cry1F (domain III) and Cry1Ac (C-terminal) [46]. Thus, some level of cross-resistance between Cry1A.105 and Cry1F proteins can be expected. A case of cross-resistance between Cry1F and Cry1A.105 in fall armyworm was already reported from Brazil [28]. Insects from the Brazilian population that were collected from the field, and further selected for Cry $1 \mathrm{~F}$ resistance, showed considerable levels of cross-resistance to Cry1A.105 and Cry1Ab, but only low levels of resistance to Cry2Ab2 [28]. Similarly, selecting for Cry1A.105 resistance in fall armyworm resulted in high levels of cross resistance to Cry1 proteins [47].

In this study, the fall armyworm population from Puerto Rico remained largely susceptible to Cry1A.105, despite being resistant to Cry1F and Cry1Ac. These results are in contrast with the aforementioned reports of significant cross-resistance between these proteins in Brazil and the United States [28,47]. However, considering the $\mathrm{EC}_{50}$ parameter, insects from the PR population were 2.4-fold 
less susceptible to this protein than the susceptible reference population. This result could indicate that susceptibility to Cry1A.105 is decreasing in this fall armyworm population, or that resistance to Cry1F and Cry1Ac confers low levels of cross-resistance to Cry1A.105. A potential reason for low or no cross-resistance between Cry1F and Cry1A.105 may be the source of the resistant population, with different resistant alleles being present in different regions. In addition, we used fall armyworms that evolved resistance in the field after exposure to Cry1F, while in the referenced studies insects were lab-selected for Cry1F resistance. This could also have selected for different resistance mechanisms in the different populations.

Similarly, our fall armyworm populations from Mexico and Puerto Rico were highly susceptible to $\mathrm{Cry} 2 \mathrm{Ab} 2$. Lower susceptibility to Cry2Ab2 protein could be anticipated in fall armyworms from Puerto Rico. However, midgut binding experiments show that $\mathrm{Cry} 2 \mathrm{Ab}$ does not share binding sites with Cry1 $\mathrm{A}$ and Cry1F proteins in Heliothis virescens, Helicoverpa zea, Helicoverpa armigera, Helicoverpa puntigera [48,49], or fall armyworm [45]. Furthermore, though the laboratory-selected Cry1F resistant fall armyworm population from Brazil showed low levels of resistance to Cry2Ab2 (10-fold), cross-resistance was ruled out by using plant bioassays [28].

Our results suggest that Cry1F and Cry1Ac resistance is established in fall armyworm from Puerto Rico. Additionally, the Puerto Rican fall armyworm population used in this work also displayed high levels of field-evolved resistance to five insecticide modes of action [12]. The resistance to Cry1F and Cry1Ac reported in this study expands on the critical status of fall armyworm management on this island, suggesting that a general mechanism of resistance might be at play in this population. On a brighter note, fall armyworm management in Puerto Rico has successfully preserved susceptibility to Cry2Ab2 and Cry1A.105 proteins to date.

The exceptional migratory capacity that fall armyworm exhibits may play a crucial role in the spread of the resistance alleles to other regions. A study analyzing mitochondrial haplotype ratios has concluded that fall armyworms from Puerto Rico showed more similarities with fall armyworm from Florida (suggesting migrations from Puerto Rico to Florida) than those from Texas and Brazil [50]. The detection of Cry1F-resistant fall armyworm in Florida in 2012-2013 [19] appears to confirm this interaction and raises concerns about the spread of Bt resistance alleles into other regions where this pest is already a management challenge. Yet, the mutation in the SfABCC2 gene conferring resistance to Cry1F in fall armyworms from Puerto Rico has not been detected in fall armyworms from Florida [41], suggesting limited migration from Puerto Rico to the US mainland.

Furthermore, it was determined that there is limited genetic interactions between fall armyworms from North and South America in the Lesser Antilles [51]. Fall armyworm movements in the Caribbean are driven by two different wind transport systems, which hinder the probability that populations located in the two hemispheres may coincide within this region [51]. In addition, fall armyworms from four Mexican states collected between 2013 and 2014 were characterized comparing amplified fragment length polymorphisms (AFLP) and haplotype ratios with populations from Texas and South America (Argentina and Brazil) [52]. The study has proposed that fall armyworms from Mexico have relatively low genetic interactions with populations from the rest of the hemisphere. This could mean that migration of resistance alleles from mainland US, Puerto Rico and South America to Mexico poses a lower risk for the evolution of resistance to Bt proteins in fall armyworms from Mexico. The extreme susceptibility to Bt Cry proteins in the populations tested in this study suggests that Bt corn has high potential for fall armyworm control in Mexico. This country may benefit from research that has been generated regarding resistance management to Bt technology, and from the lessons learned from regions where this pest has developed field-evolved resistance to Bt crops. However, this technology should not be seen as a single solution for pest problems; in addition to high dose/refuge strategy for resistance management, IPM should include other control tactics, such as crop rotation and fallow periods. The fact that our Mexican populations were highly susceptible to Bt proteins seems to indicate that they have not interacted with resistant populations from Puerto Rico or Florida. However, the limitation of this study is that we only worked with four populations from regions that were very 
far away from each other in Mexico, and there is a possibility that fall armyworms from other Mexican regions have already come in contact with fall armyworms carrying resistance alleles.

Monitoring for susceptibility to current control tools is especially important in regions where fall armyworm is a novel pest. Such is the case in several countries in Africa, Asia, and more recently in Australia, where fall armyworm's presence was officially confirmed in 2016, 2018, and 2019, respectively [6,7]. A recent study has determined that the invasive fall armyworms from six African countries likely originated from Florida and the Greater Antilles [53]. This means that fall armyworms invading Africa and Asia have already been exposed to different classes of pesticides, though specifics are yet unknown. Moreover, there have already been reports of inadequate fall armyworm control with pyrethroid insecticides in Africa [54]. While new management strategies are being designed for regional implementation, such as push-pull technology [55], farmers are still using conventional insecticides to control fall armyworm infestations [54,56]. For instance, a study from Ghana and Zambia has shown that chemical control of fall armyworm has been adopted by approximately $50 \%$ of small holder farms, mainly using pyrethroids, organophosphates and glutamate-gated chloride channel allosteric modulators [56]. Synthetic pesticides can be an expensive management tool for low income families, and most mechanic or cultural control alternatives are time and labor consuming.

GE technology might be more suitable for large-scale farmers and some small scale-farmers; however, its adoption can help reduce synthetic insecticide applications to control fall armyworm, and the efficacy of the available active ingredients can have a longer lifespan. The lessons learned from the development of Cry1F resistance in Puerto Rico, Brazil, and Argentina have recently been summarized by Huang et al. [57]. The top three factors involved in the development of Cry1F resistance were: (1) deployment of single toxins, (2) cross-resistance in fall armyworm to Cry1 proteins, and (3) Bt crops did not express high doses of the Bt proteins [57]. This highlights the need to consider these factors in future deployment of Bt toxins and determine the best strategies to incorporate resistance management plans and different actors including academia, growers, industry and regulatory agencies [58].

Our work confirms the stability of the resistance to Cry1F in fall armyworm populations from Puerto Rico. This is consistent with previous reports that indicate a lack of strong fitness costs associated with resistance to Cry1F in different populations from this island [27,42]. Additionally, an extensive work characterizing Cry1F resistance in fall armyworms from Brazil [59] has determined that resistance to this Bt protein can be due to the interaction of several resistant alleles, and can develop independently in different populations in the presence of selection pressure. This highlights the importance of studying resistance case by case, even with the same species, since resistance may evolve through different mechanisms.

\section{Conclusions}

In conclusion, this is a unique research study that shows the stability of resistance of fall armyworm from Puerto Rico to Cry1F and resistance to Cry1Ac, but the lack of cross-resistance to Cry1A.105 and Cry2Ab2. Susceptibility to all Bt proteins was found in the Mexican populations. Therefore, it is crucial to monitor the susceptibility of target pests to GE technology; any changes towards resistance development could be better addressed and understood when detected early.

Author Contributions: Conceptualization, D.M.-S. and R.G.-M.; experiments and statistical analysis, R.G.-M.; writing-original draft preparation, R.G.-M. and D.M.-S.; writing-review and editing, C.A.B., D.C., C.D., J.C., G.H., K.B. and J.W.; materials and equipment, D.M.-S., G.H., K.B. and J.W.; supervision, D.M.-S., C.D., D.C., J.W., J.C. and C.A.B.; funding acquisition, D.M.-S. All authors have read and agreed to the published version of the manuscript.

Funding: This research received no external funding. 
Acknowledgments: We would like to thank Bayer Crop Science (formerly Monsanto, St. Louis, MO, USA), for the fall armyworm colony used as the reference susceptible population, Cry1A.105 and Cry2Ab2 proteins, and CAPS buffer. We thank Corteva Agriscience (formerly Dow AgroSciences LLC, Indianapolis, IN, USA) for providing lyophilized Cry1F and Cry1Ac proteins, and CAPS buffer. We are very grateful to the effort and kind support of Henry Teran-Santofimio and Veronica Acevedo (Corteva Agriscience) for collecting and sending fall armyworm larvae from Puerto Rico. In addition, we thank Laura Martínez, Pedro and Omar Posos for collecting and sending fall armyworm larvae from Mexico. We want to thank the Department of Entomology, MSU for the Hutson Research Proposal Award. Finally, we acknowledge The Mexican National Council of Science and Technology, who supported the PhD program of Rebeca Gutierrez-Moreno.

Conflicts of Interest: The authors declare no conflict of interest.

\section{References}

1. Dew, J.A. Fall army worm. J. Econ. Entomol. 1913, 6, 361-366. [CrossRef]

2. Casmuz, A.; Juarez, M.L.; Socias, M.G.; Murua, M.G.; Prieto, S.; Medina, S.; Willink, E.; Gastaminza, G. Review of the host plants of fall armyworm, Spodoptera frugiperda (Lepidoptera: Noctuidae). Rev. Soc. Entomol. Arge. 2017, 69, 3-4.

3. Buntin, G.D.; Lee, R.D.; Wilson, D.M.; McPherson, R.M. Evaluation of YieldGard transgenic resistance for control of fall armyworm and corn earworm (Lepidoptera: Noctuidae) on corn. Fla. Entomol. 2001, 84, 37-42. [CrossRef]

4. Rodríguez-del-Bosque, L.A.; Cantú-Almaguer, M.A.; Reyes-Méndez, C.A. Corn hybrids and planting dates affect yield losses by Helicoverpa zea and Spodoptera frugiperda (Lepidoptera: Noctuidae) feeding on ears in Mexico. J. Entomol. Sci. 2012, 47, 177-184. [CrossRef]

5. Nagoshi, R.N.; Meagher, R.L.; Hay-Roe, M. Inferring the annual migration patterns of fall armyworm (Lepidoptera: Noctuidae) in the United States from mitochondrial haplotypes. Ecol. Evol. 2012, 2, 1458-1467. [CrossRef] [PubMed]

6. Goergen, G.; Kumar, P.L.; Sankung, S.B.; Togola, A.; Tamò, M. First Report of Spodoptera frugiperda (JE Smith) (Lepidoptera, Noctuidae), a new alien invasive pest in West and Central Africa. PLoS ONE 2016, 11, e0165632. [CrossRef] [PubMed]

7. Food and Agriculture Organization of the United Nations. Fall Armyworm. Available online: http: //www.fao.org/fall-armyworm/monitoring-tools/faw-map/en/ (accessed on 27 June 2020).

8. Nagoshi, R.N.; Htain, N.N.; Boughton, D.; Zhang, L.; Xiao, Y.; Nagoshi, B.Y.; Mota-Sanchez, D. Southeastern Asia fall armyworms are closely related to populations in Africa and India, consistent with common origin and recent migration. Sci. Rep. 2020, 10, 1421. [CrossRef]

9. Yu, S.J.; Nguyen, S.N.; Abo-Elghar, G.E. Biochemical characteristics of insecticide resistance in the fall armyworm, Spodoptera frugiperda (JE Smith). Pestic. Biochem. Phys. 2003, 77, 1-11. [CrossRef]

10. Belay, D.K.; Huckaba, R.M.; Foster, J.E. Susceptibility of the fall armyworm, Spodoptera frugiperda (Lepidoptera: Noctuidae), at Santa Isabel, Puerto Rico, to different insecticides. Fla. Entomol. 2012, 95, 476-478. [CrossRef]

11. Zhu, Y.C.; Blanco, C.A.; Portilla, M.; Adamczyk, J.; Luttrell, R.; Huang, F. Evidence of multiple/cross resistance to Bt and organophosphate insecticides in Puerto Rico population of the fall armyworm, Spodoptera frugiperda. Pestic. Biochem. Phys. 2015, 122, 15-21. [CrossRef]

12. Gutiérrez-Moreno, R.; Mota-Sanchez, D.; Blanco, C.A.; Whalon, M.E.; Terán-Santofimio, H.; Rodriguez-Maciel, J.C.; DiFonzo, C. Field-Evolved Resistance of the Fall Armyworm (Lepidoptera: Noctuidae) to Synthetic Insecticides in Puerto Rico and Mexico. J. Econ. Entomol. 2019, 112, 792-802. [CrossRef] [PubMed]

13. Blanco, C.A.; Portilla, M.; Jurat-Fuentes, J.L.; Sánchez, J.F.; Viteri, D.; Vega-Aquino, P.; Terán-Vargas, A.P. Susceptibility of isofamilies of Spodoptera frugiperda (Lepidoptera: Noctuidae) to Cry1Ac and Cry1Fa proteins of Bacillus thuringiensis. Southwest. Entomol. 2010, 35, 409-415. [CrossRef]

14. Storer, N.P.; Babcock, J.M.; Schlenz, M.; Meade, T.; Thompson, G.D.; Bing, J.W.; Huckaba, R.M. Discovery and characterization of field resistance to Bt Maize: Spodoptera frugiperda (Lepidoptera: Noctuidae) in Puerto Rico. J. Econ. Entomol. 2010, 103, 1031-1038. [CrossRef] [PubMed]

15. Storer, N.P.; Kubiszak, M.E.; King, J.E.; Thompson, G.D.; Santos, A.C. Status of resistance to Bt maize in Spodoptera frugiperda: Lessons from Puerto Rico. J. Invertebr. Pathol. 2012, 110, 294-300. [CrossRef] [PubMed] 
16. Bernardi, O.; Sorgatto, R.J.; Barbosa, A.D.; Domingues, F.A.; Dourado, P.M.; Carvalho, R.A.; Martinelli, S.; Head, G.P.; Omoto, C. Low susceptibility of Spodoptera cosmioides, Spodoptera eridania and Spodoptera frugiperda (Lepidoptera: Noctuidae) to genetically-modified soybean expressing Cry1Ac protein. Crop Prot. 2014, 58, 33-40. [CrossRef]

17. Farias, J.R.; Andow, D.A.; Horikoshi, R.J.; Sorgatto, R.J.; Fresia, P.; dos Santos, A.C.; Omoto, C. Field-evolved resistance to Cry1F maize by Spodoptera frugiperda (Lepidoptera: Noctuidae) in Brazil. Crop Prot. 2014, 64, 150-158. [CrossRef]

18. Omoto, C.; Bernardi, O.; Salmeron, E.; Sorgatto, R.J.; Dourado, P.M.; Crivellari, A.; Carvalho, R.A.; Willse, A.; Martinelli, S.; Head, G.P. Field-evolved resistance to Cry1Ab maize by Spodoptera frugiperda in Brazil. Pest Manag. Sci. 2016, 72, 1727-1736. [CrossRef]

19. Huang, F.; Qureshi, J.A.; Meagher, R.L., Jr.; Reisig, D.D.; Head, G.P.; Andow, D.A.; Ni, X.; Kerns, D.; Buntin, G.D.; Niu, Y. Cry1F resistance in fall armyworm Spodoptera frugiperda: Single gene versus pyramided Bt maize. PLoS ONE 2014, 9, e112958. [CrossRef]

20. Huang, F. F2 screen for resistance to Bacillus thuringiensis Cry2Ab2-maize in field populations of Spodoptera frugiperda (Lepidoptera: Noctuidae) from the Southern United States. J. Invertebr. Pathol. 2016, 138, 66-72.

21. Li, G.; Reisig, D.; Miao, J.; Gould, F.; Huang, F.; Feng, H. Frequency of Cry1F non-recessive resistance alleles in North Carolina field populations of Spodoptera frugiperda (Lepidoptera: Noctuidae). PLoS ONE 2016, 11, e0154492. [CrossRef]

22. Chandrasena, D.I.; Signorini, A.M.; Abratti, G.; Storer, N.P.; Olaciregui, M.L.; Alves, A.P.; Pilcher, C.D. Characterization of field-evolved resistance to Bacillus thuringiensis-derived Cry1F $\delta$-endotoxin in Spodoptera frugiperda populations from Argentina. Pest Manag. Sci. 2018, 74, 746-754. [CrossRef] [PubMed]

23. Blanco, C.A.; Chiaravalle, W.; Dalla-Rizza, M.; Farias, J.R.; García-Degano, M.F.; Gastaminza, G.; Mota-Sánchez, D.; Murúa, M.G.; Omoto, C.; Pieralisi, B.K. Current situation of pests targeted by Bt crops in Latin America. Curr. Opin. Insect Sci. 2016, 15, 131-138. [CrossRef] [PubMed]

24. Burtet, L.M.; Bernardi, O.; Melo, A.A.; Pes, M.P.; Strahl, T.T.; Guedes, J.V. Managing fall armyworm, Spodoptera frugiperda (Lepidoptera: Noctuidae), with Bt maize and insecticides in southern Brazil. Pest Manag. Sci. 2017, 73, 2569-2577. [CrossRef] [PubMed]

25. Luttrell, R.G.; Wan, L.; Knighten, K. Variation in susceptibility of noctuid (Lepidoptera) larvae attacking cotton and soybean to purified endotoxin proteins and commercial formulations of Bacillus thuringiensis. J. Econ. Entomol. 1999, 92, 21-32. [CrossRef]

26. Hardke, J.T.; Leonard, B.R.; Huang, F.; Jackson, R.E. Damage and survivorship of fall armyworm (Lepidoptera: Noctuidae) on transgenic field corn expressing Bacillus thuringiensis Cry proteins. Crop Prot. 2011, 30, 168-172. [CrossRef]

27. Vélez, A.M.; Spencer, T.A.; Alves, A.P.; Crespo, A.L.B.; Siegfried, B.D. Fitness costs of Cry1F resistance in fall armyworm, Spodoptera frugiperda. J. Appl. Entomol. 2014, 138, 315-325. [CrossRef]

28. Bernardi, D.; Salmeron, E.; Horikoshi, R.J.; Bernardi, O.; Dourado, P.M.; Carvalho, R.A.; Martinelli, S.; Head, G.P.; Omoto, C. Cross-resistance between Cry1 proteins in fall armyworm (Spodoptera frugiperda) may affect the durability of current pyramided Bt maize hybrids in Brazil. PLoS ONE 2015, 10, e0140130. [CrossRef]

29. Blanco, C.A.; Pellegaud, J.G.; Nava-Camberos, U.; Lugo-Barrera, D.; Vega-Aquino, P.; Coello, J.; Terán-Vargas, A.P.; Vargas-Camplis, J. Maize pests in Mexico and challenges for the adoption of integrated pest management programs. J. Integr. Pest Manag. 2014, 5, E1-E9. [CrossRef]

30. Tabashnik, B.E.; Brevault, T.; Carriere, Y. Insect resistance to Bt crops: Lessons from the first billion acres. Nat. Biotechnol. 2013, 31, 510-521. [CrossRef] [PubMed]

31. Monnerat, R.; Martins, E.; Queiroz, P.; Praca, L.; Soares, C.M. Insect resistance to Bt toxins in Brazil and Latin America. In Bt Resistance: Characterization and Strategies for GM Crops Producing Bacillus Thuringiensis Toxins; Soberón, M., Gao, A., Bravo, A., Eds.; CABI: Wallingford, UK, 2015; pp. 26-35.

32. Robertson, J.L.; Smith, K.C.; Savin, N.E.; Lavigne, R.J. Effects of dose selection and sample size on the precision of lethal dose estimates in dose-mortality regression. J. Econ. Entomol. 1984, 77, 833-837. [CrossRef]

33. Abbott, W.S. A method of computing the effectiveness of an insecticide. J. Econ. Entomol. 1925, 18, $265-267$. [CrossRef]

34. Finney, D.J. Probit Analysis, 3rd ed.; Cambridge University Press: Cambridge, UK, 1971. 
35. SAS Institute. SAS User's Guide Version 9.3; SAS Institute Inc.: Cary, NC, USA, 2011; Available online: http://support.sas.com/index.html (accessed on 26 November 2020).

36. OriginLab. Origin 8 User Guide; OriginLab Corporation: Northampton, MA, USA, 2007.

37. Sims, S.B.; Greenplate, J.T.; Stone, T.B.; Caprio, M.A.; Gould, F.L. Monitoring strategies for early detection of Lepidoptera resistance to Bacillus thuringiensis insecticidal proteins. In ACS Symposium Series; ACS Publications: Washington, DC, USA, 1996; Volume 645, pp. 229-242.

38. Rivero-Borja, M.; Rodríguez-Maciel, J.C.; Urzúa Gutiérrez, J.A.; Silva-Aguayo, G.; Chandrasena, D.I.; Felix-Bermudez, N.C.; Storer, N.P. Baseline of Susceptibility to the Cry1F Protein in Mexican Populations of Fall Armyworm. J. Econ. Entomol. 2020, 113, 390-398. [CrossRef] [PubMed]

39. Vélez, A.M.; Spencer, T.A.; Alves, A.P.; Moellenbeck, D.; Meagher, R.L.; Chirakkal, H.; Siegfried, B.D. Inheritance of Cry1F resistance, cross-resistance and frequency of resistant alleles in Spodoptera frugiperda (Lepidoptera: Noctuidae). Bull. Entomol. Res. 2013, 103, 700-713. [CrossRef] [PubMed]

40. Vélez, A.M.; Vellichirammal, N.N.; Jurat-Fuentes, J.L.; Siegfried, B.D. Cry1F resistance among Lepidopteran pests: A model for improved resistance management? Curr. Opin. Insect Sci. 2016, 15, 116-124. [CrossRef] [PubMed]

41. Banerjee, R.; Hasler, J.; Meagher, R.; Nagoshi, R.; Hietala, L.; Huang, F.; Narva, K.; Jurat-Fuentes, J.L. Mechanism and DNA-based detection of field-evolved resistance to transgenic Bt corn in fall armyworm (Spodoptera frugiperda). Sci. Rep. 2017, 7, 1-10. [CrossRef]

42. Jakka, S.R.K.; Knight, V.R.; Jurat-Fuentes, J.L. Fitness costs associated with field-evolved resistance to Bt maize in Spodoptera frugiperda (Lepidoptera: Noctuidae). J. Econ. Entomol. 2014, 107, 342-351. [CrossRef] [PubMed]

43. Yang, F.; Kerns, D.L.; Brown, S.; Kurtz, R.; Dennehy, T.; Braxton, B.; Head, G.; Huang, F. Performance and cross-crop resistance of Cry1F-maize selected Spodoptera frugiperda on transgenic Bt cotton: Implications for resistance management. Sci. Rep. 2016, 6, 28059. [CrossRef]

44. Yang, F.; Kerns, D.L.; Head, G.; Brown, S.; Huang, F. Susceptibility of Cry1F-maize resistant, heterozygous, and susceptible Spodoptera frugiperda to Bt proteins used in the transgenic cotton. Crop Prot. 2017, 98, 128-135. [CrossRef]

45. Hernández-Rodríguez, C.S.; Hernández-Martínez, P.; Van Rie, J.; Escriche, B.; Ferré, J. Shared midgut binding sites for Cry1A. 105, Cry1Aa, Cry1Ab, Cry1Ac and Cry1Fa proteins from Bacillus thuringiensis in two important corn pests, Ostrinia nubilalis and Spodoptera frugiperda. PLoS ONE 2013, 8, e68164.

46. Biosafety Clearing-House. Gene and DNA Sequence. 2014. Available online: https://bch.cbd.int/database/ record.shtml? documentid=43771 (accessed on 12 June 2020).

47. Niu, Y.; Head, G.P.; Price, P.A.; Huang, F. Performance of Cry1A. 105-selected fall armyworm (Lepidoptera: Noctuidae) on transgenic maize plants containing single or pyramided Bt genes. Crop Prot. 2016, 88, $79-87$. [CrossRef]

48. Gouffon, C.; Van Vliet, A.; Van Rie, J.; Jansens, S.; Jurat-Fuentes, J.L. Binding sites for Cry2Ae toxin from Bacillus thuringiensis on heliothine brush border membrane vesicles are not shared with Cry1A, Cry1F or Vip3A toxins. Appl. Environ. Microbiol. 2011, 77, 3182-3188. [CrossRef] [PubMed]

49. Caccia, S.; Hernández-Rodríguez, C.S.; Mahon, R.J.; Downes, S.; James, W.; Bautsoens, N.; Van Rie, J.; Ferre, J. Binding site alteration is responsible for field-isolated resistance to Bacillus thuringiensis Cry2A insecticidal proteins in two Helicoverpa species. PLoS ONE 2010, 5, e9975. [CrossRef] [PubMed]

50. Nagoshi, R.N.; Meagher, R.L.; Jenkins, D.A. Puerto Rico fall armyworm has only limited interactions with those from Brazil or Texas but could have substantial exchanges with Florida populations. J. Econ. Entomol. 2010, 103, 360-367. [CrossRef] [PubMed]

51. Nagoshi, R.N.; Fleischer, S.; Meagher, R.L.; Hay-Roe, M.; Khan, A.; Murúa, M.G.; Silvie, P.; Vergara, C.; Westbrook, J. Fall armyworm migration across the Lesser Antilles and the potential for genetic exchanges between North and South American populations. PLOS ONE 2017, 12, e0171743.

52. Nagoshi, R.N.; Rosas-García, N.M.; Meagher, R.L.; Fleischer, S.J.; Westbrook, J.K.; Sappington, T.W.; Hay-Roe, M.; Thomas, J.M.; Murúa, G.M. Haplotype profile comparisons between Spodoptera frugiperda (Lepidoptera: Noctuidae) populations from Mexico with those from Puerto Rico, South America, and the United States and their implications to migratory behavior. J. Econ. Entomol. 2015, 108, 135-144. [CrossRef] 
53. Nagoshi, R.N.; Goergen, G.; Tounou, K.A.; Agboka, K.; Koffi, D.; Meagher, R.L. Analysis of strain distribution, migratory potential, and invasion history of fall armyworm populations in northern Sub-Saharan Africa. Sci. Rep. 2018, 8, 1-10. [CrossRef]

54. Matthews, G. The spread of fall armyworm (FAW) Spodotera frugiperda. Outlooks Pest Manag. 2018, 29, $213-214$. [CrossRef]

55. Midega, C.A.; Pittchar, J.O.; Pickett, J.A.; Hailu, G.W.; Khan, Z.R. A climate-adapted push-pull system effectively controls fall armyworm, Spodoptera frugiperda (JE Smith), in maize in East Africa. Crop Prot. 2018, 105, 10-15. [CrossRef]

56. Tambo, J.A.; Day, R.K.; Lamontagne-Godwin, J.; Silvestri, S.; Beseh, P.K.; Oppong-Mensah, B.; Phiri, N.A.; Matimelo, M. Tackling fall armyworm (Spodoptera frugiperda) outbreak in Africa: An analysis of farmers' control actions. Int. J. Pest Manag. 2020, 66, 298-310. [CrossRef]

57. Huang, F. Resistance of the fall armyworm, Spodoptera frugiperda, to transgenic Bacillus thuringiensis Cry1F corn in the America: Lessons and implications for Bt corn IRM in China. Insect Sci. 2020. [CrossRef]

58. Carriere, Y.; Brown, Z.S.; Downes, S.J.; Gujar, G.; Epstein, G.; Omoto, C.; Storer, N.P.; Mota-Sanchez, D.; Jørgensen, P.S.; Carroll, S.P. Governing evolution: A socioecological comparison of resistance management for insecticidal transgenic Bt crops among four countries. Ambio 2020, 49, 1-16. [CrossRef] [PubMed]

59. Boaventura, D.; Ulrich, J.; Lueke, B.; Bolzan, A.; Okuma, D.; Gutbrod, O.; Geibel, S.; Zeng, Q.; Dourado, P.M.; Martinelli, S.; et al. Molecular characterization of Cry1F resistance in fall armyworm, Spodoptera frugiperda from Brazil. Insect Biochem. Mol. Biol. 2020, 116, 103280. [CrossRef] [PubMed]

Publisher's Note: MDPI stays neutral with regard to jurisdictional claims in published maps and institutional affiliations.

(C) 2020 by the authors. Licensee MDPI, Basel, Switzerland. This article is an open access article distributed under the terms and conditions of the Creative Commons Attribution (CC BY) license (http://creativecommons.org/licenses/by/4.0/). 